\title{
Analysis of Some of the International Environmental Principles and Their Relevance to Nigeria's Quest for Environmental Security
}

\author{
Benson Okwuchukwu OKORO, LL.M, BL. \\ Associate at Egonu Chambers, Onitsha.
}

\begin{abstract}
In an effort to tackle the numerous environmental challenges confronting the nation and to ensure environmental security in Nigeria, the Federal Government incorporated some of the international environmental principles into the nation's environmental laws, policies and strategies. Despite the above effort, it is disheartening to know that the environmental challenges confronting the nation are on the increase. The paper examines some of the international environmental principles that have been incorporated into the nation's environmental laws, policies and strategies and the factors bedeviling the use of the principles as a vehicle towards achieving environmental security in Nigeria. The paper finds that the factors militating against the use of the principles as a vehicle towards achieving environmental security in Nigeria are multifaceted. They include enforcement problem, inadequacy of punishment, corruption and Paucity of funds. The paper concludes by making appropriate recommendations for review and reform.
\end{abstract}

Keywords: Environmental Principles, Environmental Security, Sustainable Development, Environmental Impact Assessment, Challenges.

DOI: $10.7176 / \mathrm{JLPG} / 86-14$

Publication date:June $30^{\text {th }} 2019$

\section{Introduction}

The developmental effort of man in all spheres which include manufacturing, processing, industrialization, mineral and other resources exploitation, housing, construction, agriculture, rural and urban growth and development have subjected the environment to changes that are being witnessed today. ${ }^{1}$ The threat which the above human development processes pose to the environment is alarming. The emission of greenhouse gases and chlorofluorocarbon (CFCS) and their impact on the ozone layer, the consequential phenomenon of global warming, climate change, the rising sea level worldwide and the advent of acid rain, increased desertification, deforestation, loss of biodiversity, marine pollution and impoverishment of the ecosystem are but a few examples of the consequences of laissez faire in the management of nature's resources. ${ }^{2}$ In order to combat these environmental challenges, the United Nations came up with the international environmental principles which are to act as a guide to the international community for the preservation and enhancement of human environment. In its quest for environmental security, Nigeria had incorporated some of the international environmental principles into the nation's environmental laws, policies and strategies. It is therefore disheartening to know that despite the incorporation of some of the international environmental principles into the nation's environmental laws, policies and strategies, the environmental challenges confronting the country are on the increase. Nigeria is confronted with a lot of environmental challenges which includes flooding, desertification, loss of biodiversity, deforestation, global warming, climate change, the rising sea levels and the advent of acid rain, land, air and water pollution as a result of oil spillage; emission of greenhouse gases and CFCS; improper waste management; unstructured urbanization; improper utilization of inorganic fertilizer and herbicides and mining activities, etc. The paper examines some of the international environmental principles that have been incorporated into the nation's environmental laws, policies and strategies and the factors bedeviling the use of the principles as a vehicle towards achieving environmental security in Nigeria.

\section{Definition of Terms/Clarification of Concepts}

\subsection{Environmental Security}

Environmental security has been variously defined, for example the Common Wealth states defined Environmental security as the state of protection of vital interests of the individual, society, natural environment from threats resulting from anthropogenic and natural impacts on the environment. ${ }^{3}$ For the purpose of this paper,

A.O. Obabori, A. O. O. Ekpu and B.P. Ojealaro "An Appraisal of the Concept of Sustainable Environment under Nigerian Law," Journal of Human Ecology 28, no. 2,(2009): 135.

L. Atsegbua, V. Akpotaire and F. Dimowo, Environmental Law in Nigeria: Theory and Practice, $2^{\text {nd }}$. ed., (Benin City, Ambik Press, 2010),79.

Science Direct, "Environmental Security,” https://www.sciencedirect.com/topic/earth-and-planetary-sciences/environmentalsecurity. accessed on 30 May, 2019. 
Environmental Security may be defined as the relative public safety from environmental dangers caused by natural or human processes due to ignorance, accident, mismanagement or design and originating within or across national borders. ${ }^{1}$ Environmental security is central to national security.

\section{International Environmental Principles}

Most of the international environmental principles are traceable to the United Nations Conference on the Human Environment held at Stockholm in 1972 and the United Nations Conference on Environment and Development (UNCED) held in Rio de Janeiro, Brazil. The Stockholm Conference agreed upon a Declaration containing 26 principles which were to act as a guide to the international community for the preservation and enhancement of human environment ${ }^{2}$ while the Rio Conference agreed upon a Declaration containing 27 principles and known as Rio Declaration. The Rio Declaration was a further step from the Stockholm Declaration towards more definite international legal obligations on states to protect the environment. ${ }^{3}$ Subsequent efforts were made by the United Nations and individual states to advance these international environmental principles through the instrumentality of conventions, protocols, treaties and agreements. Some of the principles are examined below:

\subsection{The Principle of Sustainable Development}

The principle of sustainable development was defined by the 1987 Brundtland Report as a development that meets the needs (in particular the essential needs of the world's poor) of the present without compromising the ability of future generations to meet their own needs. ${ }^{4}$ Sustainable development imposes the idea of limitations on the environment's capacity to meet present and futures needs. The reasoning in sustainable development is to ensure that the environment is safe for human habitation and to check the adverse effect of emerging environmental problems. The principle obtained its impetus from the 1992 United Nations Conference on Environment and Development (UNCED) Declaration which states that:

"Human beings are the centre of concern for sustainable development. They are entitled to a healthy and productive life in harmony with nature". 5

Some critics adduced ulterior motives to the concept by alleging that it was meant to slow development in the developing countries under the guise of environmental consciousness and concluded that it is an extension of the neo-liberalist ideology. ${ }^{6}$

\subsubsection{Public Participation in Environmental Issues}

Principle 10 of the Rio Declaration states that:

"Environmental issues are best handled with the participation of all concerned citizens at the relevant level. At the national level, each individual shall have appropriate access to information concerning the environment that is held by public authorities including information on hazardous materials and activities in their communities and the opportunity to participate in decision making process. States shall facilitate and encourage public awareness and participation by making information widely available. Effective access to judicial and administrative proceedings including redress and remedy shall be provided."

The 1998 Aarhus, Denmark Convention embodies three fundamental principles of public participation in the development, management and protection of the environment. It encompasses access to information, public participation in decision making and access to justice in environmental matters by persons likely to be affected by development activities. ${ }^{7}$ These three pillars depend on each other for full implementation of the objectives of the Convention. These three pillars are briefly examined below:

\section{Access to information}

The access to information encompasses the right of the public to request information from public authorities and the obligation of the authorities to respond favorably to this request by providing the required information; and the right of the public to receive information based on the obligation of public authorities to collect and disseminate information of public interest in their possession. ${ }^{8}$

\section{Public participation in Decision Making}

Public participation in decision making is covered under Articles 6 to 8 of the Aarhus Convention. Under Article

Millennium Project Home, "Environmental Security Study," https://107.22.164.43/millenium/es-2def.html.accessed on 30 May, 2019.

Atsegbua, Akpotaire and Dimowo, Environmental Law, 72.

Atsegbua, Akpotaire and Dimowo, Environmental Law, 73

Philippe Boudes, "United Nations Conference on the Human Environment," www.britannica.com/topic/United-Nations-Conferenceon-the-Human-Environment. accessed on 22 April, 2019.

Rio Declaration, Principle 1.

Gozie Ogbodo, "The Paradox of the Concept of Sustainable Development under Nigeria's Environmental Law," Journal of Sustainable Development 3, no.3,(2010): 201.

Atsegbua, Akpotaire and Dimowo, Environmental Law, 249

Atsegbua, Akpotaire and Dimowo, Environmental Law, 250. 
6 of the Convention, members of the public who may be affected by or who are otherwise interested in the decision-making process of specific activities are required to be informed either by public notice or individually and in an adequate, timely and effective manner. ${ }^{1}$ Article 8 covers public or citizens' participation in the preparation of laws, rules and other legally binding instruments.

\section{Access to Justice}

Access to justice in this context means, that the public has the right to have recourse to judicial or administrative procedure, in order to redress any perceived environmental injustice.

\subsubsection{Requirement to Conduct Environmental Impact Assessment}

Environmental impact assessment (EIA) refers to the process by which changes in the environment as a result of development are assessed to measure how beneficial or deleterious these changes might be. It is a policy and management tool for both planning and decision making. Environmental impact assessment is an anticipatory tool, that is, it takes place before an action is carried out. Environmental impact assessment has been adopted by developed and developing countries to ensure that decision makers take cognizance of the environmental implications in deciding whether to proceed with a project. ${ }^{2}$ Principle 13 of the Stockholm Declaration which is the rationale for environmental impact assessment states that:

"In order to achieve a more rationale management of resources and thus improve the environment, states should adopt an integrated and coordinated approach to their development planning so as to ensure that development is compatible with the need to protect and improve the environment for the benefit of their population."

Principle 17 of the Rio Declaration emphasized that:

"Environmental impact assessment as a national instrument shall be undertaken for proposed activities that are likely to have a significant adverse impact on the environment and are subject to a decision of a competent national authority."

\subsubsection{Polluter Pays Principle}

The principle came into focus in 1972 when in its recommendations, the Organization for Economic Cooperation and Development (OECD) Council on Guiding Principles Concerning International Economic Environmental Policies stated that:

"The principle to be used for allocating cost of pollution prevention and control measures to encourage rational use of scarce environmental resources and to avoid distortions in international trade and investment is the so called polluter pays principle".

The polluter pays principle is an embodiment of the idea that the polluter should bear the expense of carrying out the environmental measures decided by the public authorities to ensure that the environment is in an acceptable condition. It includes accidental pollution control and clean up costs. National authorities are encouraged to promote the internalization of environmental costs and the use of economic instruments taking into account the approach that the polluter should in principle bear the cost of pollution with due regard to the public interest and without distorting international trade and investment. The polluter pays principle is geared towards enhancing fairness, justice, economic efficiency, the harmonization of international environmental policies and the definition of costs that are allocated within a state. The implementation of the polluter pays principle includes attachment of fee to the polluting activities which could be in emission fee or an excise tax on the sales of products associated with the polluting activity. ${ }^{3}$

\subsubsection{Principle of Preventive Action}

The main aim of this principle is to require the prevention of damage to the environment and to reduce, limit or control the actions which might cause or risk such harm. Under the principle of preventive action, a state may be under the obligation to prevent damage to the environment within its own jurisdiction. The preventive action requires steps to be taken at an early stage to reduce pollution, rather than waiting to restore contaminated areas. The principle was enshrined in the 1972 Stockholm Declaration as the obligation of states to ensure that the activities within their jurisdiction or control do not cause harm to the environment of other states or of areas beyond the limits of national jurisdiction. ${ }^{4}$ The principle was reiterated in the Rio Declaration. ${ }^{5}$ To ensure this principle, states have established authorization procedures, commitments to environmental standards, ways to access information, the use of penalties, and the need to carry out environmental impact assessments. ${ }^{6}$

Ibid.

V. O. Aigbokhaevbo, 'International Environmental Law Principles: Sustainability Challenges,' University of Benin Journal of Private and Property Law 1, no.1 (2010): 163.

Ibid at 151.

Stockholm Declaration, Principle 21.

Rio Declaration, Principle 2.

Max Valverde Soto' "General Principles of International Environmental Laws," ILSA Journal of Int'l \& Comparative Law 3, no.1 (1996): 193. https://nsuworks.nova.edu/cgi/viewcontent.cgi?article=1069\&content=ilsajournal. accessed on 30 May, 2019. 
4. Relevance of the International Environmental Principles to Nigeria's Quest for Environmental Security In its quest for environmental security, Nigeria had incorporated some of the international environmental principles into the nation's environmental laws, policies and strategies. The principles are seen by the policy makers as a vehicle towards attainment of environmental security in Nigeria. The principles are now the bedrock of the nation's environmental laws, policies and strategies. This part examines some of the principles that have been incorporated into the nation's environmental laws, policies and strategies.

\subsection{The Principle of Sustainable Development in Nigeria}

Like all developing countries, Nigeria was faced with the dilemma of pursuing development efforts at the expense of environmental degradation or adopting environmentally safe practices at the expense of faster development. ${ }^{1}$ The adoption of the National Policy on the Environment (NPE), and the Objectives and Strategies for Nigeria's Agenda 21 introduced sustainable development practices and policies into environmental governance in the country. Both instruments aim at integrating environment into development planning at all levels of government and the private sector. ${ }^{2}$ The first National Policy on the Environment launched by the Federal Government on 27 November 1989 was drastically reviewed in 1999 with the aim of incorporating new concepts, principles, and changes into the environmental governance adopted in the Rio Declaration on Environment and Development and the other 1992 Rio instruments. In order to achieve the principle of sustainable development, the following policy goals are enumerated in the 1999 National Policy on the Environment: ${ }^{3}$

(a) To secure for all Nigerians a quality of environment adequate for their health and well being;

(b) To conserve and use the environment and national resources for the benefit of present and future generations;

(c) To restore, maintain and enhance the ecosystem and ecological processes essential for the functioning of the biosphere to preserve biological diversity and the principle of optimum sustainable yield in the use of living natural resources;

(d) To raise public awareness and promote understanding and essential linkages between environment and development and to encourage individuals and community participation in environmental improvement efforts; and

(e) To co-operate in good faith with other countries, international organizations/agencies to achieve optimal use of trans-boundary natural resources and effective prevention or abatement of trans-boundary environmental degradation.

Paragraph 2 of the NPE states in general term that the goal of the NPE is to achieve sustainable development in Nigeria. Paragraph 3.0 of the NPE categorically states that the NPE is basically a programme of actions rooted in a conceptual frame within which the linkages between environmental problems on the one hand and their causes, effects, and solutions, on the other hand, can be discerned. ${ }^{4}$ By expressing sustainable development as a programme of actions in the NPE, it is at best a soft law. This must have informed the Federal Government's decision to clearly list in Paragraph 3.0(a-e) of the NPE the different ways of achieving the policy and by extension sustainable development. One of the ways is to give it legal clothing. This is the basis of paragraph 3.0(d) of the NPE which states thus:

"enactment of necessary legal instruments designed to strengthen the activities and strategies recommended by this policy".

To actualize the provision of paragraph 3.0(d) of the NPE, the National Environmental Standards and Regulations Enforcement Agency (NESREA) Act, $2007^{5}$ and other environmental legislations were enacted. ${ }^{6}$ Section 7(a) of the NESREA Act stipulates as part of the Agency's functions, the enforcement of policies (NPE inclusive) on environmental matters. Section 1(2)(c) of the NESREA Act provides that the Agency shall have, among others things, the responsibility for the sustainable development of Nigeria's natural resources in general. Going by this provision, sustainable development is expressed as a rule of law, which creates a duty for the Agency to ensure its enforcement, particularly when a combined effect of sections 1 (2) (a) and 7(a) of the NESREA Act provides that the Agency shall be the enforcement agency for the purpose of ensuring compliance with the sustainable development of Nigeria's natural resources. Section 2 of the NESREA Act, 2007 stated the objectives of the enforcement agency as follows:

Ogbodo, "The Paradox", 203.

E.E. Okon, "The Legal Status of Sustainable Development in the Nigerian Environmental Law" Afe Babalola University Journal of Sustainable Development, Law \& Policy 7, no.2,(2016): 117

Atsegbua, Akpotaire and Dimowo, Environmental Law, 91.

Okon, "The Legal Status", 123.

Cap. N164 Laws of the Federation of Nigeria 2010.

Okon, "The Legal Status", 123. 
"The Agency, shall, subject to the provisions of this Act, have responsibility for the protection and development of the environment, biodiversity conservation and sustainable development of Nigeria's natural resources in general and environmental technology, including coordination and liaison with relevant stakeholders within and outside Nigeria on matters of enforcement of environmental standards, regulations, rules, laws, policies and guidelines"

The Act also under Section 7, enumerated the functions of the Agency, which are geared towards sustainably developing the natural resources of the country. Under Section 7 (e), for instance, the Agency is empowered to: "enforce compliance with guidelines and legislations on sustainable management of the ecosystem, biodiversity conservation and the development of Nigeria's natural resources." Some of the Regulations made pursuant to the NESREA Act made provisions for sustainable development. For instance Regulation 2(c)(g) of the National Environmental (Desertification Control and Drought Mitigation) Regulations, 2011 expressly states that the objectives of Part 1 (General Provisions on Desertification Control) of the Regulations are to: (c) encourage the sustainable use of fuel wood through the use of more efficient and energy saving devices with a view to encouraging their wider use and adoption at all levels; and (g) ensure sustainable agriculture and range management practices, improved animal husbandry and management of water resources in the desertification prone areas with a view to achieving sustainable livelihood, poverty reduction and wealth creation; through introduction of modern and affordable production technologies to resource poor farming communities. Regulation 3(a) of the National Environmental (Wetland, River Banks and Lake Shores Protection) Regulations, 2009 provides that 'The following principles shall be observed in regulating all wetlands: (a) Wetland resources shall be utilised in a sustainable manner compatible with the continued presence of wetlands and their hydrological functions and services;'

\subsubsection{Polluter Pays Principle in Nigeria}

Nigeria's National Policy on the Environment, 1999 recognizes the polluter pays principle. ${ }^{1}$ It provides that:

"Nigeria is committed to a national environmental policy that will ensure sustainable development based on proper management of the environment.... This policy, in order to succeed must be built on the following sustainable development principles: .... The polluter pays principle (PPP) which suggests that the polluter should bear the cost of preventing and controlling pollution". ${ }^{2}$

The policy also recognizes that sectoral policies, environmental laws and regulations are important, but cannot, alone, be expected to deal with the problems of environment and development. Prices, markets and governmental economic policies also play a complementary role in shaping attitudes and behavior towards the environment. It therefore has as one of its strategies, to institutionalize polluter pays principle, so that the polluter bears the cost of environmental degradation or pollution; thus providing the positive incentives to limit degradation or pollution of the environment. ${ }^{3}$ It recognizes also the use of economic instruments and incentives as parts of strategies to propel the development process in the desired direction as follows:

(a) incorporate environmental costs in the decisions of producers and consumers so as to reverse the tendency to treat the environment as a "free good" and to stop passing these costs on to other parts of society or to future generations;

(b) integrate social, environmental and other costs of negative environmental externalities into economic activities so that prices will appropriately reflect the true and total value of resources and contribute towards the prevention of environmental degradation;

(e) develop and implement a mechanism for charging emission fees and fines for all pollutants and effluents (based on quantity, quality and detrimental effects) thereby internalizing all costs and other negative externalities into the production process and output prices;

(f) impose penalty taxes, fines, and charges for non- compliance to environmental standards and regulations so that violations to such regulation become costly to the violators;

Again, Nigeria's Agenda 21 on the Environment provides for the internalization of environmental costs through the use of economic instruments in the management of natural resources. ${ }^{4}$ The NESREA Act recognizes and provides for the polluter pays principle as follows:

"Where an offence under subsection (1) of this section is committed by a body corporate, it shall on conviction, be liable to a fine, not exceeding $\$ 1,000.000$ and an additional fine of $\$ 50,000$ for every day the offence subsists." 5

Section 28 provides:

"The Minister for the purpose of implementing the provisions of this Act, shall by regulations prescribe any specific removal method, financial responsibility level for owners or operators of vessels, or

Gina Elvis-Imo, “An Analysis of the Polluter Pays Principle in Nigeria,” Ajayi Crowder University Law Journal 1, no.1, (2016): 21. Nigeria's National Policy on the Environment 1999, Paragraph 1.

Ibid, Paragraph 11 (d).

Agenda 21 on the Environment (made sequel to the United Nations Convention on Environment and Development).

NESREA Act, Section 27 subsection (3) 
onshore or offshore facilities notice and reporting requirements."

Similarly some of the Regulations made pursuant to the NESREA Act like, the National Environmental (Chemicals, Pharmaceuticals, Soap and Detergent Manufacturing Industries) Regulation, 2009, ${ }^{1}$ and the National Environmental (Sanitation and Wastes Control) Regulations, $2009^{2}$ made provisions for polluter pays principle. These provisions presuppose that the polluter would bear the costs of removing the polluting substance or discontinuing the polluting activity, and to abate and/or clean up the affected area. There are plethora of other legislations and guidelines embodying the polluter pays principle, examples include the Environmental Impact Assessment (EIA) $\mathrm{Act}^{3}$, the Harmful Wastes (Special Criminal Provisions etc) $\mathrm{Act}^{4}$, the National Oil Spill Detection and Response Agency (NOSDRA) $\mathrm{Act}^{5}$ and the Environmental Guidelines and Standards for the Petroleum Industry in Nigeria (EGASPIN) ${ }^{6}$ Section 6 (2) (3) of the NOSDRA Act provides that:

"the failure to clean up the impacted site, to all practical extent including remediation shall attract a further fine of one million naira".

The above section thus makes a polluter responsible for cleaning up an impacted site and a fine of one million naira for the failure to clean up the site. Also, Paragraph 8.1 of EGASPIN provides that:

"a spiller shall be liable for the damage from a spill for which he is responsible. Where more than one spiller is liable, the liability shall be joint and several".

These legislations set out regulations and standards that prohibit pollution and every form of environmental hazards. In addition, the parties responsible for the pollution have the responsibility of managing the process of remediation of any acts of contamination of the environment as well as compensate those who suffer the consequences of such pollution.

\subsubsection{Requirement to Conduct Environmental Impact Assessment in Nigeria}

In Nigeria, the 1981-86 National Development Plan Guidelines required that feasibility studies for all project both private and public should be accompanied by environmental impact statements. ${ }^{7}$ Again in 1990, the second session of the National Council on the Environment issued a communiqué which in part recognized that environmental impact assessment (EIA) is an indispensable prerequisite for effective implementation of the National Policy on the Environment for Sustainable Development, and directed that with effect from March, 1991, EIA becomes a prerequisite for all development projects in the country and therefore urged FEPA (now NESREA) to establish without delay EIA guidelines and procedures for operation in all the states of the Federation and Abuja. ${ }^{8}$ This declaration hastened the process culminating in the subsequent enactment of the Environment Impact Assessment Act, 1992. ${ }^{9}$ The EIA Act of 1992 is consistent with the National Policy on the Environment which requires the prior environmental assessment of proposed activities which may affect the environment or the use of natural resources as one of the major strategies for implementation of the national policy. ${ }^{10}$ The EIA of 1992 insists that environmental impact assessment should be carried out and be approved before the commencement of any developmental project which is likely to have 'significant effect' on the environment. Such effects could be physical, biological, economic and social. Although the Act did not clarify what amounts to 'significant effect', however, a further reading of 'environmental effect' provides a reasonable clue. Under the interpretation section of the Act, 'environmental effect' was defined as follows:

"any change that the project may cause to the environment, whether any such change occurs within or outside Nigeria, and includes any effect of any such change on health and socio-economic conditions".

The determination of whether a project could have a 'significant effect' or 'environmental effect' rests with a review panel set up specifically to make such a determination. Section 1 of the Act stated that one of the objectives of the environmental impact assessment is:

"to establish before a decision taken by any person, authority, corporate body or unincorporated body including the Government of the Federation, State or Local Government intending to undertake or authorise the undertaking of any activity that may likely or to a significant extent affect the environment or have environmental effects on those activities shall first be taken into account”.

Regulation 5(3) provides that "In the event of an accident resulting in an adverse impact on the environment whether socioeconomically or health wise, the facility shall be responsible for (a) the cost of damage assessment, control and clean-up; (b) remediation; (c) reclamation or restoration; (d) compensation to affected parties; and (d) cost of damage assessment and control."

2 Regulation 14 provides that "All generators of waste, owners or occupiers of premises where wastes are generated shall be legally and financially responsible for the safe and environmentally sound disposal of waste."

Cap. E12 Laws of the Federation of Nigeria 2010

Cap. H1 Laws of the Federation of Nigeria 2010

Cap. N157 Laws of the Federation of Nigeria 2010

Environmental Guidelines and Standards for the Petroleum Industry in Nigeria 2002, Published by the Department of Petroleum Resources (DPR), Paragraph 8.1, 'Liability'

Atsegbua, Akpotaire and Dimowo, Environmental Law, 231.

Atsegbua, Akpotaire and Dimowo, Environmental Law, 232.

Ibid.

Ibid. 
It is worthy of clarification, that the initial Agency charged with the enforcement of the EIA Act was the Federal Environmental Protection Agency, which was established under the Federal Environmental Protection Agency Act (FEPA Act). The NESREA Act has repealed the FEPA Act; consequently, the NESREA Agency has inherited the enforcement of the EIA Act.

\subsubsection{Public Participation in Environmental Issues in Nigeria}

The relevance of public participation in the Nigeria's quest for environmental security would be discussed in the light of the three fundamental principles of public participation in the development, management and protection of the environment as expounded by the 1998 Aarhus, Denmark Convention. They are access to information, public participation in decision making and access to justice in environmental matters by persons likely to be affected by development activities.

\section{Access to information}

Access to information particularly on environmental issues does not exist in Nigeria. Consequently, the media becomes the only source of official information. The reason for the secrecy on information is because of official corruption. Corruption has become an endemic problem in every facet of Nigerian society. ${ }^{1}$ To guarantee access to information, the Federal Government enacted Freedom of Information Act 2011. The extent this Act has been of any help with regards to access to information is yet to be seen.

\section{Public Participation in Decision Making}

This aspect of public participation in environmental issues, have found expression in the Environmental Impact Assessment Act, 1992. The procedure for achieving public participation as provided under sections, $7^{2}, 25^{3}$, $39^{4}$ and $41^{5}$ of the Act are as follows:

a) The developer submits an EIA to the Agency,

b) The Agency examines the report and makes same available to government agencies, members of the public, experts in any relevant discipline and interested groups who are given the opportunity to participate in the EIA review process at a given location for at least 21 working days on national and local dailies and announcements on electronic media,

c) The review panel meetings are held in the public so that stakeholders and the public can utilize this opportunity to put forward their views and concern for consideration, ${ }^{6}$

d) The Review Panel or Mediation Report shall again be made available to the public for comments following which the Review Panel may either approve or reject the EIA.

e) Where the EIA is approved ${ }^{7}$, a monitoring or follow-up programme is drawn up and still made available to the public before a certificate is issued.

The Act clearly recognizes public concern in the EIA review process and spells out the procedure for notifying the public of this action and the modalities for filing comments. In addition, the Act details the stages of review where the public can be involved such as public display, mediation and review panel. Since 1995, Nigerian laws have provided for stakeholder consultation by way of a continuous programme of public participation, public forums, the public display and review of documents and public attendance at panel reviews. ${ }^{8}$ The provisions of the EIA Act in Nigeria appear to be quite comprehensive as it involves the public almost in all the stages of EIA process. However, it is disheartening that the law does not provide for an effective sanction for failure to consult the public in EIA process.

\section{Access to Court}

Section 20 of the 1999 Constitution of the Federal Republic of Nigeria (as amended) ${ }^{9}$ provides that:

"The State shall protect and improve the environment and safeguard the water, air and land, forest and wildlife of Nigeria".

The only handicap to this constitutional provision is that it comes under Chapter II on Fundamental Objectives and Directive Principles of State Policy (FODPSP). These objectives are non-justiciable and thus lack enforcement in the Nigerian Courts. Section 6(6)(c) of the 1999 Constitution makes all the provisions of Chapter

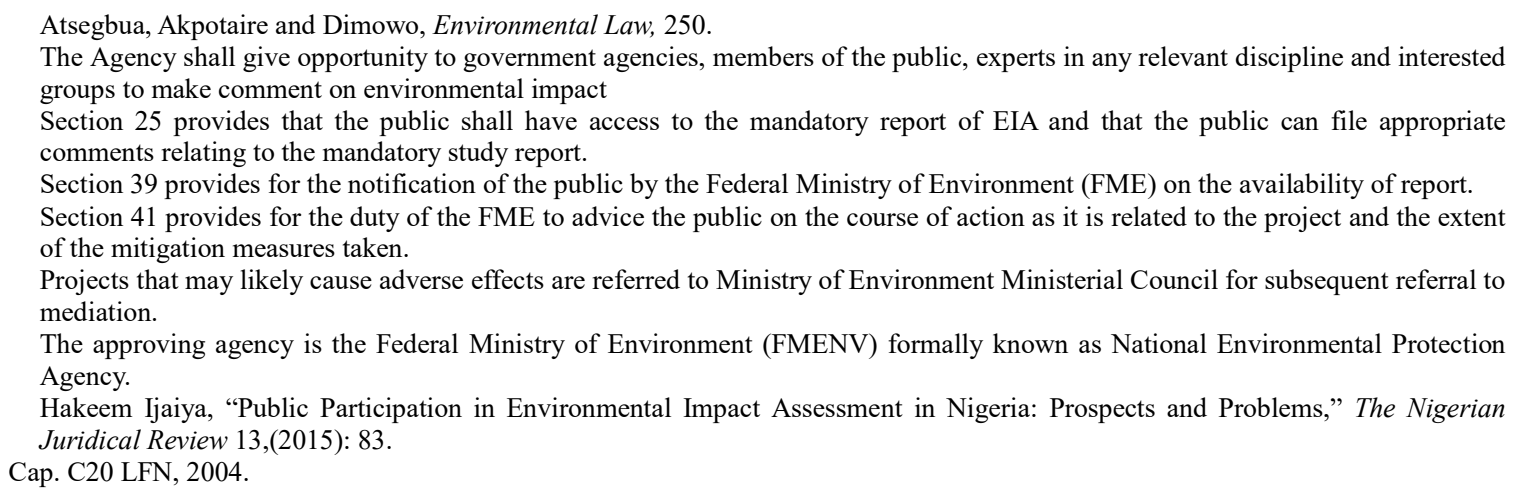


II non-justiciable under the Nigerian Courts. The above position was given judicial impetus in the case of Okogie v. Lagos State Government, ${ }^{1}$ the Court of Appeal held that the directive principles of State Policy in Chapter II of the Constitution is non-justiciable and must conform to and run subsidiary to Fundamental Rights. The Court held, in effect, that an individual could not rely on FODPSP to assert any legal right. The Supreme Court also in A. G. of Ondo State v. Attorney General Federation ${ }^{2}$ maintained that the provisions of FODPSP in Chapter II of the Constitution remain non-justiciable. They are mere declarations that lack the force of law and cannot be enforced by legal process except translated or elevated to the status of law by legislation. Further, Section 1(2) of the NESREA Act vests on the Agency (NESREA) the power to enforce environmental standards, regulations, rules, laws, policies and guidelines. Similarly, section 6(1)(a) of the NOSDRA Act, 2006 vests on the Agency (NOSDRA) the power to ensure compliance with all existing environmental legislation in the petroleum sector. The import of the above legislations when read jointly is that there is no individual right of action under the existing environmental legislations. Anybody who is not authorized by the relevant government agency to enforce environmental standards, regulations, rules, laws, policies and guidelines will be confronted with the issue of locus standi. Also any person that feels that the government or its relevant agency is not carrying out its duties in accordance with the existing legislations cannot institute an action against the government to compel the government or its agency to carry out its functions; or if by omission or commission, the government failed to carry out its environmental functions and such led to a person suffering an injury, such person cannot institute an action against the government to seek redress. The only remedy that is left for such person is to seek redress under the Common Law, like Negligence, Rule in Ryland v. Fletcher ${ }^{3}$ and Nuisance which have their demerits. In all it will be convenient to submit that access to Court in environmental matters is not guaranteed in Nigeria.

\subsubsection{Principle of Preventive Action in Nigeria}

This principle has found most expression in the Harmful Waste (Special Criminal Provisions) Act, $1988 .{ }^{4}$ The Act prohibits dumping of harmful waste on any land or in any territorial waters or contiguous zone or exclusive economic zone of Nigeria or its inland waterways. ${ }^{5}$ The Act defined "Harmful waste" to mean:

"any injurious, poisonous, toxic, or noxious substance and in particular, includes nuclear waste emitting any radioactive substance if the waste in such quantity, whether with any other consignment of the same or of different substance, as to subject any person to the risk of death, fatal injury or incurable impairment of physical and mental health; and the fact that the harmful waste is placed in a container shall not by itself be taken to exclude any risk which might be expected to arise from harmful waste."

The Act provides for life imprisonment for anybody found guilty of dumping harmful waste. ${ }^{7}$ Where the person is a body corporate and it is proved that the crime was committed with the consent or connivance of a director, manager, secretary, or other similar officer of the body corporate; such persons as well as the body corporate shall be liable to be proceeded against and punished accordingly. ${ }^{8}$ The Act also provide for life imprisonment for anybody found guilty of an attempt to commit the crime. ${ }^{9}$ The Act provided that where any damage has been caused by any harmful waste which has been deposited or dumped on any land or territorial waters or contiguous zone or exclusive economic zone of Nigeria or its inland waterways, any person who deposited, dumped or imported the harmful waste or caused the harmful waste to be so deposited, dumped or imported shall be liable for the damage except where the damage - (a) was due wholly to the fault of the person who suffered; (b)was suffered by person who voluntarily accepted the risk thereof. ${ }^{10}$

\section{Factors Militating Against the Use of the International Environmental Principles as a Vehicle for the Attainment of Environmental Security in Nigeria}

Despite the efforts made by Nigeria to incorporate some of the international environmental principles into the nation's environmental laws, policies and strategies with the bid to use the principles as a vehicle towards attainment of environmental security, the nation is still plagued with enormous environmental issues. The paper therefore identified the following as some of the factors militating against maximizing the objectives of adopting or incorporating the principles into the nation's environmental laws, policies and strategies.

1. Poor enforcement- The inability of the policy makers and implementers to properly enforce the

(1981) 2 N.C.L.R, 337.

(2002) 9 N.W.L.R (PT 772), 2.

(1886) L.R. Ex. 265.

Harmful Waste (Special Criminal Provisions) Act, 1988, Cap. H1 LFN, 2004.

Ibid, section 2 (a).

Ibid, section 15 .

Ibid, section 6 .

Ibid, section 7 .

Ibid, section 8 .

Ibid, section 12(1) 
existing legislations is one of the major reasons why environmental insecurity is on the increase in Nigeria. It has also without any doubt encouraged the low level of compliance with the environmental laws in Nigeria. ${ }^{1}$ One thing is to incorporate the international environmental principles into the national environmental laws, policies and strategies and another thing is to enforce them. It has been shown above that some of the Principles have been incorporated into the nation's environmental laws, policies and strategies but the challenge therefore lies with their enforcement.

2. Economic consideration- Although Nigeria had incorporated the international environmental principles into the nation's environmental laws, policies and strategies, however, it cannot be forgotten in a hurry that Nigeria is a developing economy and like most other developing economies, it tends to prioritize economic development over environmental security. For instance, petroleum plays a large role in the Nigeria economy accounting for $95 \%$ of government's export earnings and $10.45 \%$ to the real gross domestic product. ${ }^{2}$ Petroleum exploration and production activities are the major cause of pollution in Nigeria. The Nigeria National Petroleum Corporation holds at least $60 \%$ equity interest in the joint ventures with the international oil companies. That explains why the oil industry is being over protected by the government and why the government is always reluctant to effectively enforce environmental laws in the oil industry.

3. Corruption- One innate and cancerous problem in Nigeria is corruption. ${ }^{3}$ It is one problem which virtually the whole country seems to disclaim and detest, but which unfortunately is the bane of the country. It is the issue most talked about in the country particularly in this present democratic regime of President Muhammadu Buhari and yet no solution has been found and none is in the proximity or in sight. Corruption has been a significant hindrance to the effective enforcement of environmental laws in Nigeria. Corruption has caused some officers of NESREA and NOSDRA to overlook environmental law violation and prefer their own personal gains to effective enforcement of the laws. The officers of the agencies engage in corruption through bribery during the granting of permits or conducting inspections. ${ }^{4}$ Besides being rooted in the lack of transparency and accountability, corruption is commonly nurtured by weak institutions, low salaries, a high level of bureaucracy, and low professionalism. $^{5}$

4. Issue of locus standi. There is no individual right of action under the existing environmental legislations. Anybody who is not authorized by the relevant government agency to enforce environmental standards, regulations, rules, laws, policies and guidelines is normally confronted with the issue of locus standi.

5. Provision of section 6(6)(c) of the Constitution which renders section 20 non-justiceable. Section 20 of the 1999 Constitution of the Federal Republic of Nigeria I999 as amended which provides that it is the duty of the State to protect and improve the environment and safeguard the air and land, forest and wild life of Nigeria is rendered non-justiceable by virtue of section 6(6) (c ) of the same constitution. It then appear that it would take the intervention of the National Assembly to make the provisions of chapter II enforceable. It therefore means that any person that feels that the government is not carrying out the environmental duty cannot institute an action against the government, to compel the government to carry out its duty; or if by omission or commission the government failed to carry out its environmental functions and it led to a person suffering an injury, such person cannot institute an action against the government to seek redress.

6. Inadequacy of Sanctions. - Without real consequences for environmental violations, there is no incentive for multinational corporations to respect the environment in which they operate. The current environmental laws in Nigeria incorporated the principle of polluter pays principle; however, they do not contain sanctions stiff enough to deter would be polluters. Under the present regime, it is cheaper to pollute than to adopt pollution abatement practices.

7. Paucity of funds - No enforcement agency can effectively function without money. Lack of funds affects the enforcement agencies in various degrees ranging from under staffing, lack of qualified staff, inability to effectively prosecute cases in Court etc. ${ }^{6}$

Okon, "The Legal Status", 129

Federal Ministry of Budget and National Planning, "Nigeria's Oil Sector Contribution to GDP Lowest in OPEC- Blueprint." www.national planning.gov.ng/index.php/news-media/news/news-summary/333-nigeria-s-oil-sector-contribution-to-gdp-lowestin-opec-blue-blueprint.accessed on 6 June, 2019.

The judiciary which was earlier regarded as a sacred institution which is free from corruption does not enjoy that status any longer. Recently some senior members of the bench were standing trial for several corrupt charges. See Ade Adesomoju, "Ngwuta's Trial: I fired Prosecutor, He Didn't Withdraw, Says AGF," Punch, February 13, 2017, https://www.Punchng.com accessed on 30 May, 2019. N.F. Stewart, "A Roadmap for the Effective Enforcement of Environmental Laws in Nigeria," National Environmental Law Review 2,(2011): 46

Dr. Ngeri Benedo, the Director-General of NESREA stated that the major challenge of the Agency is poor funding which she said 


\section{Recommendations}

Flowing from the above premises, the paper therefore makes the following recommendations for review and reform:

1. The current environmental laws should be reviewed to provide for stiffer sanctions against the people that indulge in activities that harm the environment. This will no doubt effectively deter would be offenders.

2. The extant environmental laws and regulations will be ineffective if they are not complied with or enforced. The government and its relevant agencies must therefore change their attitude in the enforcement of the extant regulations and laws. Effective enforcement of the extant regulations and laws will go a long way in limiting the incidents of environmental damage in the country.

3. Section 20 of the Constitution of the Federal Republic of Nigeria 1999 should be transferred to Chapter IV of the Constitution, which deals with fundamental human rights, so as to make environmental right as provided by section 20 of the Constitution justiceable.

4. Nigeria should enact laws that provide the public with the means to scrutinize and hold accountable the agencies tasked with the enforcement of environmental laws.

5. Nigeria should enact laws that allow members of the public to, under certain circumstances, bring enforcement actions against private parties that fail to comply with relevant statutory requirements.

6. The environmental enforcement agencies must be well equipped and properly funded by the government to be able to perform optimally.

\section{Conclusion}

Commendably, Nigeria has shown commitment towards the attainment of environmental security through the incorporation of some of the international environmental principles into the nation's environmental laws, policies and strategies; and making the principles the bedrock for her environmental laws, policies and strategies. However, the country will continue to experience upsurge in environmental insecurity unless the above identified challenges are tackled headlong and the government begin to put the health and environmental consideration of the country in front burner when considering economic policies.

\section{References}

A.O. Obabori, A. O. O. Ekpu and B.P. Ojealaro "An Appraisal of the Concept of Sustainable Environment under Nigerian Law,” Journal of Human Ecology 28, no. 2,(2009): 135.

L. Atsegbua, V. Akpotaire and F. Dimowo, Environmental Law in Nigeria: Theory and Practice, $2^{\text {nd }}$. ed., (Benin City, Ambik Press, 2010),79.

Science Direct, "Environmental Security,"

https:/www.sciencedirect.com/topic/earth-and-planetary sciences/environmental-security. accessed on 30 May, 2019.

Millennium Project Home, "Environmental Security Study,"

https://107.22.164.43/millenium/es-2def.html.accessed on 30 May, 2019.

Philippe Boudes, "United Nations Conference on the Human Environment," www.britannica.com/topic/UnitedNations-Conference-on-the-Human-Environment. accessed on 22 April, 2019.

Gozie Ogbodo, "The Paradox of the Concept of Sustainable Development under Nigeria's Environmental Law," Journal of Sustainable Development 3, no.3,(2010): 201.

V. O. Aigbokhaevbo, “International Environmental Law Principles: Sustainability Challenges,' University of Benin Journal of Private and Property Law 1, no.1 (2010): 163.

Max Valverde Soto' "General Principles of International Environmental Laws," ILSA Journal of Int'l \& Comparative Law 3, no.1 (1996): 193.

https://nsuworks.nova.edu/cgi/viewcontent.cgi?article=1069\&content=ilsajournal. accessed on 30 May, 2019.

E.E. Okon, "The Legal Status of Sustainable Development in the Nigerian Environmental Law" Afe Babalola University Journal of Sustainable Development, Law \& Policy 7, no.2,(2016): 117.

Gina Elvis-Imo, “An Analysis of the Polluter Pays Principle in Nigeria," Ajayi Crowder University Law Journal 1, no.1, (2016): 21.

Hakeem Ijaiya, "Public Participation in Environmental Impact Assessment in Nigeria: Prospects and Problems," The Nigerian Juridical Review 13,(2015): 83.

Federal Ministry of Budget and National Planning, "Nigeria's Oil Sector Contribution to GDP Lowest in OPEC- Blueprint." www.national planning.gov.ng/index.php/news-media/news/news-summary/333nigeria-s-oil-sector-contribution-to-gdp-lowest-in-opec-blue-blueprint.accessed 6 June, 2019. 
Ade Adesomoju, "Ngwuta's Trial: I fired Prosecutor, He Didn’t Withdraw, Says AGF," Punch, February 13, 2017, https://www.Punchng.com accessed 30 May, 2019.

N.F. Stewart, "A Roadmap for the Effective Enforcement of Environmental Laws in Nigeria," National Environmental Law Review 2,(2011): 46

Joseph Chibueze, "After Five Years, it's Time to Bite," http://csrwatchinternationalnigeria.wordpress.com/2012/11/18/nesrea-after-five-year-its-time-to-bite-byjoseph-chibueze/. accessed on 30 April, 2019. 